\title{
Effect of Location, Cultivar, and Diseases on Grain Yield of Soft Red Winter Wheat in Wisconsin
}

Karen V. Lackermann, Department of Plant Pathology, Shawn P. Conley, John M. Gaska, and Mark J. Martinka, Department of Agronomy, and Paul D. Esker, Department of Plant Pathology, University of Wisconsin-Madison, Madison 53706

\begin{abstract}
Lackermann, K. V., Conley, S. P., Gaska, J. M., Martinka, M. J., and Esker, P. D. 2011. Effect of location, cultivar, and diseases on grain yield of soft red winter wheat in Wisconsin. Plant Dis. 95:1401-1406.

Knowledge is limited about the impact of foliar diseases on wheat yield in Wisconsin. The objective of this study was to compare yield and diseases of wheat cultivars in several locations in Wisconsin in 2009 and 2010. Thirty-six wheat cultivars were planted in a randomized complete block design at field sites near Arlington, Chilton, and Lancaster, WI. At a fourth location, Janesville, WI, the design was a split plot with foliar fungicide application at Zadoks growth stage (GS) 45 at the whole-plot level and cultivar at the subplot level. Disease assessments were made four times during the growing season for powdery mildew (PM), Septoria/Stagonospora leaf blotch (SLB), and leaf rust. Incidence and severity of Fusarium head blight were assessed on

100 heads per plot at GS 85. Linear mixed-model analyses were used to study the effects of location, cultivar, and disease on grain yield $(\alpha=$ 0.05). Overall, SLB and PM were the most prevalent diseases. SLB severity was uniform among locations and PM was most prevalent at Arlington and Chilton. In both years, yield was affected by location, cultivar, location-cultivar interaction, and location-SLB and locationPM interactions. Yield was also negatively affected by PM in 2010. No effect of fungicide on disease severity or yield was observed at Janesville in either year. These results suggest that cultivar selection and location strongly influence grain yield in Wisconsin and that powdery mildew is capable of reducing grain yield.
\end{abstract}

Common wheat (Triticum aestivum L.) is a staple crop for $40 \%$ of the world's population and is planted on 200 million ha worldwide (2). Annually, global yield losses due to wheat diseases in the field or in storage are estimated to be $20 \%$ (2). Although the total wheat production area is unlikely to increase in the future, increases in global population will necessitate higher wheat yields per unit area (2). Reducing yield loss due to disease may be a key component in this effort. In Wisconsin, soft red winter wheat production has more than doubled over the past 10 years in response to increasing value and greater worldwide demand (24). Although wheat diseases are known to occur within the state, little is known about the impact of disease on yield and growers lack a comprehensive management strategy for control of wheat diseases. Given the geographic diversity of Wisconsin's wheat production areas, it is hypothesized that there are differences in cultivar response to disease across these different locations. An understanding of these interactions between cultivar and location is critical to determine the factors that affect disease development and impact yield.

In Wisconsin, winter wheat has a fairly limited acreage; as a result, research on this crop has been limited. However, because Wisconsin differs both geographically and climatically from other growing areas of the United States, information about wheat diseases collected in these other areas may not be directly applicable in Wisconsin. Furthermore, due to the diversity of wheat-growing regions within Wisconsin, it is likely that results will differ among regions. For this reason, it is critical that research is conducted in the state and that it is done at multiple locations.

In Wisconsin, the primary foliar diseases of interest include powdery mildew (Blumeria graminis (DC.) Speer; syn. Erysiphe

Corresponding author: P. D. Esker, E-mail: esker@wisc.edu

* The $e$-Xtra logo stands for "electronic extra" and indicates that a supplementary table is available in the online edition.

Accepted for publication 2 June 2011.

doi:10.1094/PDIS-01-11-0005

(C) 2011 The American Phytopathological Society graminis f. sp. tritici E.J. Marchal), wheat leaf rust (Puccinia triticina f. sp. tritici Roberge ex Desm.), and the Septoria/Stagonospora leaf blotch complex (SLB) (Septoria tritici Desm. and Stagonospora nodorum (Berk.) E. Castell. \& Germano). Each of these foliar pathogens can infect wheat and cause disease throughout the growing season and all may affect the flag leaf shortly after its emergence (Zadoks growth stage [GS] 37). The heading disease of greatest concern is Fusarium head blight (FHB; Fusarium graminearum Schwabe).

Management of wheat diseases is primarily focused on the use of resistant cultivars and the application of foliar fungicides $(17,25)$. Efficacious use of foliar fungicides requires information about disease incidence and severity, in combination with knowledge of both the disease resistance characteristics of the cultivar and the different pathogen life cycles, and an understanding of the economic costs and benefits of fungicide application (28). Although a great deal of research has been done on wheat diseases, currently there is minimal information available about the impact of diseases on the wheat cultivars commonly planted in Wisconsin or about the role of fungicides for disease management in the state. It has been demonstrated that, when growers lack information on actual yield losses caused by the major wheat diseases, they are unable to make firm economic and agronomic decisions regarding disease management $(20,28)$.

Although there is extensive research on the interaction of cultivar and environment and their effect on yield $(1,18,29)$, very little is known about the quantitative impact of wheat diseases on grain yield, especially in Wisconsin. Due to the emphasis placed on yield performance by both growers and wheat breeders, it is important to understand the effect of disease on grain yield. Therefore, the objectives of this study were to (i) assess the occurrence and severity of wheat diseases in the primary winter-wheat-growing regions of Wisconsin and (ii) determine the effects of location, cultivar, and disease on grain yield.

\section{Materials and Methods}

Locations and experimental design. In conjunction with the Wisconsin Winter Wheat Variety Performance Tests $(8,9)$, disease and grain yield data were collected over two growing seasons, 2008-09 and 2009-10, hereafter referred to as 2009 and 2010, at 
four locations in Wisconsin: Arlington $\left(43^{\circ} 18.1^{\prime} \mathrm{N}, 89^{\circ} 20.4^{\prime} \mathrm{W}\right)$, Chilton $\left(44^{\circ} 2.5^{\prime} \mathrm{N}, 88^{\circ} 8.3^{\prime} \mathrm{W}\right)$, Janesville $\left(42^{\circ} 43.6^{\prime} \mathrm{N}, 89^{\circ} 1.5^{\prime} \mathrm{W}\right)$, and Lancaster $\left(42^{\circ} 50.5^{\prime} \mathrm{N}, 90^{\circ} 48.1^{\prime} \mathrm{W}\right)$ (Table 1). These locations represent a range of production situations in Wisconsin. For example, the distance from Lancaster to Chilton is approximately 260 $\mathrm{km}$. Lancaster is located in the driftless area of Wisconsin and most fields are cropped on contour strips due to relatively steep slopes. The Chilton location is a seed production farm that has greater crop diversity than Arlington and Janesville, where wheat fields are sown into areas that are typically a three-crop rotation of corn-soybean-wheat.

At three locations (Arlington, Chilton, and Lancaster), the experimental design was a randomized complete block design with four replications. At Janesville, the experimental design was randomized complete block in a split-plot arrangement with four replications. The whole-plot factor was foliar fungicide and the subplot factor was wheat cultivar. The foliar fungicide treatment was either no fungicide or Quilt (azoxystrobin and propiconazole; Syngenta Crop Protection, Inc., Greensboro, NC; 1.02 liters active ingredient/ha with $\mathrm{H}_{2} \mathrm{O}$ at 140.3 liters/ha) applied at GS 39 .

Plots measured $2.4 \mathrm{~m}$ wide $(0.19-\mathrm{m}$ row spacing) by $7.6 \mathrm{~m}$ long, with seven center harvest rows and two nonharvest border rows. Fields were seeded at 3.7 million viable seeds per hectare using a grain drill with cone units. The center seven rows were harvested using a self-propelled combine. Soil type, previous crop history, and planting, flowering, and harvest date information for each location are provided in Table 1 .

Performance trials consisted of both public and private cultivars and experimental lines submitted by small-grain breeders (Table 2 ). Over the 2 years of study, there were 36 cultivars planted at all locations.

Foliar disease assessments. Foliar disease assessments were made four times each growing season: GS 30 (jointing), GS 31-32 (first and second node), GS 39-41 (flag leaf emergence), and GS 60 (heading). Dates for all assessments are provided in Table 3. In 2009 , three stems were arbitrarily selected and destructively sampled from both the left and right border rows within each plot $(n=$ 6). All plant samples were kept at $4{ }^{\circ} \mathrm{C}$ and rated within 4 days. In 2010, disease assessments were made directly in the field on six arbitrarily selected stems from the border rows in each plot. Assessments were made in border rather than harvest rows because the requirements of the Performance Tests prohibited damage or disruption of the plants in the harvest rows.

Two measures were obtained per stem for each leaf disease. Incidence was based on the presence or absence of symptoms and signs on an individual stem ( $n=6$ stems per plot) and severity was based on the percentage of each leaf area exhibiting symptoms or signs (0-to-100 scale, by leaf). The leaves that were assessed changed as the growing season progressed $(6,19)$. At GS 30, disease severity was assessed only on the newest emerged leaf whereas, at GS 31-32, disease severity was assessed on the upper three leaves (flag-1, flag-2, and flag-3). For both the GS 39-41 and GS 60 assessments, disease severity was assessed on the upper four leaves (flag, flag-1, flag-2, and flag-3).

A weighted disease severity score was calculated for each stem (modified from Lipps and Madden; 20) as weighted disease severity $=(4 \times$ severity on flag leaf $)+(3 \times$ severity on flag- 1 leaf $)+(2$ $\times$ severity on flag- 2 leaf $)+$ (severity on flag-3 leaf). A weighted value was used to account for the greater contribution to final grain yield made by the upper leaves compared with lower leaves $(6,14,26)$. The weighted severity values from each of the four assessment timings were used to calculate the area under the disease progress curve (AUDPC) value based on the methods of Madden et al. (22). Time intervals were defined as the number of days between assessments.

FHB disease assessments. Incidence and severity of FHB were assessed at GS 85 (soft dough). Assessment dates are provided in Table 3. Assessments were done on 50 consecutive heads from each border row for a total of 100 heads per plot. Wheat heads were visually assessed in the field for the presence or absence of FHB (incidence) as well as the percentage of each head with visual symptoms (severity). From these two measures, an FHB index (FHBI) was calculated for each plot as FHBI $=$ (percent incidence $\times$ percent severity)/100 (5). FHBI is a measure of the mean percentage of symptomatic spikelets per spike (23). Following harvest, the percentage of Fusarium-damaged kernels (FDK) was

Table 2. Wheat cultivars that were tested in the Wisconsin Winter Wheat Performance Tests in 2009 and 2010

\begin{tabular}{lll}
\hline Entry $^{\mathbf{a}}$ & \multicolumn{1}{c}{ Source } & \multicolumn{1}{c}{ Cultivar } \\
\hline 69 & Public & Hopewell \\
73 & Public & Kaskaskia \\
90 & Pro Seed Genetics & PRO 200 \\
140 & Pioneer & 25R47 \\
213 & Public & Truman \\
215 & Pro Seed Genetics & PRO 220 \\
235 & Jung & 5988 \\
237 & Legacy & LW 860 \\
238 & Pioneer & 25R51 \\
250 & Pro Seed Genetics & PRO 240 \\
256 & AgriPro/Syngenta & Branson \\
258 & Diener & D 502 \\
261 & FS Seed & FS 628 \\
267 & Legacy & LW 862 \\
268 & Legacy & LW 863 \\
277 & Public & Sunburst \\
278 & Public & IL 01-11934 \\
284 & AgriPro/Syngenta & W 1377 \\
287 & Diener & D 487 \\
294 & Legacy & LW 870 \\
295 & Pioneer & $25 R 62$ \\
296 & PIP & 701 \\
297 & PIP & 720 \\
299 & PIP & 760 \\
301 & Excel/Welter & 442 \\
312 & Dyna-Gro & 9911 \\
316 & Jung & 5830 \\
318 & Legacy & LW 1050 \\
319 & Pioneer & $25 R 39$ \\
322 & PIP & 717 \\
324 & PIP & 729 \\
327 & Public & IL 04-24668 \\
328 & Public & P 02444A1-23-9 \\
330 & Public & Sisson \\
331 & Public & Milton \\
336 & Public & \\
\hline & &
\end{tabular}

${ }^{a}$ Entry number corresponds to a unique identification given to each cultivar tested in the Wisconsin Winter Wheat Performance Tests.

Table 1. Soil type, previous crop history, and planting, flowering, and harvest dates for each Wisconsin performance test location

\begin{tabular}{llllccc}
\hline Year & Location & Soil type & Previous crop & Planting date & Flowering date & Harvest date \\
\hline 2009 & Arlington & Plano silt loam & Soybean & 26 September 2008 & 7 June 2009 & 30 July 2009 \\
& Chilton & Red clay & Pea & 30 September 2008 & 8 June 2009 & 5 August 2009 \\
& Janesville & Plano silt loam & Soybean & 13 October 2008 & 3 June 2009 & 29 July 2009 \\
& Lancaster & Plano silt loam & Alfalfa & 26 September 2008 & 6 June 2009 & 4 August 2009 \\
2010 & Arlington & Plano silt loam & Soybean & 30 September 2009 & 26 May 2010 & 13 July 2010 \\
& Chilton & Red clay & Oat & 1 October 2009 & 25 May 2010 & 27 July 2010 \\
& Janesville & Plano silt loam & Soybean & 13 November 2009 & 30 May 2010 & 20 July 2010 \\
& Lancaster & Plano silt loam & Alfalfa & 29 September 2009 & 22 May 2010 & 16 July 2010 \\
\hline
\end{tabular}


assessed for a 200-kernel sample for each plot. The percentage of FDK is a measure of the number of visibly shriveled and diseased kernels.

Loss of plots due to winterkill and other factors in 2009 and 2010. During the 2009 growing season, there was significant stand loss due to winterkill at both Arlington and Chilton. Criteria used to exclude plots for disease assessments were if the level of winterkill was greater than $50 \%$ or if the amount of stand loss in the border rows would limit the ability to obtain a reliable estimate of disease incidence and severity. To account for winterkill-associated stand loss at Arlington and Chilton, plot yield values were adjusted based on an analysis of covariance, which used percent survival in each plot as a covariate $(8,21)$.

In 2010, the Janesville location was planted later than other trial locations due to a late corn and soybean harvest (Table 1). Stand quality was variable during the spring and, as a result, plots with greater than 50\% stand loss were not included in any data analyses.

Statistical analyses. To determine whether there were critical assessment times that best correlated with yield, analyses were conducted to examine different leaf disease severities with grain yield at each assessment time. All correlations were calculated in SAS using PROC CORR (v. 9.1.3; SAS Inc., Cary, NC). Within each location, separate correlations were calculated for each disease with grain yield-assessment time. For the leaf diseases, correlations used the weighted severity values calculated from each of the four foliar assessment timings.

To determine whether there was an effect of location, cultivar, and disease (AUDPC or FHBI value) on wheat grain yield, linear mixed-model analyses were conducted using PROC MIXED in SAS. Separate models were used to look at the effect of each disease (SLB, leaf rust, powdery mildew, and FHBI value) on grain yield. Disease data were either log-transformed (SLB and FHBI, 2009 and 2010; powdery mildew, 2009) or square-root transformed (powdery mildew, 2010). For these analyses, cultivar and location were considered as fixed effects, disease data (AUDPC or FHBI) were considered as continuous covariates, and block was considered to be a random effect. Fungicide-treated plots from Janesville were excluded from all analyses that examined the effect of location. Additionally, only those cultivars $(n=36)$ included in both 2009 and 2010 were examined. Separate analyses were done for 2009 and 2010. Mean comparisons of fixed effects were based on Fisher's protected least significant difference. The level of significance for all analyses was 0.05 .

A single site analysis was also done for the data from Janesville to examine the effect of fungicide on grain yield. For this analysis, cultivar and fungicide were considered fixed effects, disease data (AUDPC) were considered as continuous covariates, and block was considered a random effect. As in the multilocation analysis, individual analyses were done for each disease and for each year (2009 and 2010). The level of significance was 0.05 .

\section{Results}

Weather conditions and grain yield over sites and years. Monthly air temperature and precipitation data for May, June, and July are presented in Table 4. In general, conditions were cooler in 2009, which extended the grain-fill period (Table 1, harvest date).
Rainfall in 2009 was less than in 2010 and, although harvest dates were earlier in 2010 than in 2009 , high rainfall amounts during late June into July 2010 delayed harvest dates at some locations.

Mean grain yield was similar between 2009 and 2010, with yields of 5.0 and $5.3 \mathrm{t} / \mathrm{ha}$, respectively (Table 5). In 2009, grain yield was highest at Chilton and lowest at Janesville. In 2010, grain yield was highest at Arlington and lowest at Chilton. Within analyses that examined the effect of different wheat diseases on yield, it was also found that grain yield was affected by location, cultivar, and a location-cultivar interaction each year. Data for combinations of year, location, and cultivar are provided in Supplementary Table 1.

Correlations between disease and yield. Generally, correlations between weighted disease severity at each assessment time and yield were low $(r<0.4)$ for all diseases, although a few were significant (Table 6). At Chilton, SLB was negatively correlated with yield at GS 39 in both 2009 and 2010 (Table 6). Powdery mildew was negatively correlated with yield at Arlington (GS 39), Chilton (GS 31-32, GS 39, and GS 60), and Lancaster (GS 39) in 2010 (Table 6). Leaf rust was negatively correlated with yield at Lancaster in both 2009 and 2010, although the significant correlation was observed at GS 60 in 2009 and at GS 39 in 2010 (Table 6). However, not all significant correlations were negative. In 2009, SLB was positively correlated with grain yield at both Arlington (GS 31-32 and GS 39) and Chilton (GS 60) (Table 6). In 2009, FHB was correlated with yield only at Lancaster, which had the

Table 4. Summary air temperature $\left({ }^{\circ} \mathrm{C}\right)$ and precipitation $(\mathrm{mm})$ for May, June, and July 2009 and 2010 Wisconsin locations ${ }^{\mathrm{a}}$

\begin{tabular}{lllrr}
\hline Year, location & Weather variable & May & June & July \\
\hline 2009 & & & & \\
Arlington & Temperature & 14.5 & 19.4 & 19 \\
& Precipitation & 95.0 & 113.5 & 55.1 \\
Chilton & Temperature & 13.4 & 17.7 & 18.8 \\
& Precipitation & 59.4 & 51.8 & 36.3 \\
Janesville & Temperature & 14.9 & 19.7 & 19.2 \\
& Precipitation & 50.0 & 117.6 & 59.9 \\
Lancaster & Temperature & 14.5 & 19.5 & 18.8 \\
& Precipitation & 97.3 & 65.5 & 132.1 \\
2010 & & & & \\
Arlington & Temperature & 15.4 & 19.6 & 22.8 \\
& Precipitation & 91.7 & 169.4 & 222.8 \\
Chilton & Temperature & 15.0 & 18.8 & 22.5 \\
& Precipitation & 68.6 & 184.2 & 146.8 \\
Janesville & Temperature & 16.3 & 20.7 & 23.6 \\
& Precipitation & 97.8 & 150.4 & $78.2^{\mathrm{b}}$ \\
Lancaster & Temperature & 15.5 & 20.4 & 23.3 \\
& Precipitation & $26.9 \mathrm{~b}$ & 171.2 & 214.9
\end{tabular}

a Weather data were obtained using an on-site weather station (Hobo Series U30 Weather Station; Onset Computer Corporation, Bourne, MA) that was situated close to field sites but not within the field. Weather stations were typically placed out at each location during the month of April, depending on field conditions.

b Precipitation for Janesville (July 2010) and Lancaster (May 2010) were considered an underestimate of the precipitation due to plugged tip buckets. Local precipitation totals based on the Wisconsin State Climatology office were $170.2 \mathrm{~mm}$ (Janesville) and $116.8 \mathrm{~mm}$ (Lancaster).

Table 3. Dates when disease assessments were made at each Wisconsin performance test location ${ }^{\mathrm{a}}$

\begin{tabular}{|c|c|c|c|c|c|c|}
\hline Year & Location & GS 30 & GS 31-32 & GS 39-41 & GS 60 & GS 85 \\
\hline 2009 & $\begin{array}{l}\text { Arlington } \\
\text { Chilton } \\
\text { Janesville } \\
\text { Lancaster }\end{array}$ & $\begin{array}{l}15 \text { May } \\
14 \text { May } \\
10 \text { May } \\
12 \text { May }\end{array}$ & $\begin{array}{l}21 \text { May } \\
22 \text { May } \\
18 \text { May } \\
20 \text { May }\end{array}$ & $\begin{array}{r}1 \text { June } \\
2 \text { June } \\
26 \text { May } \\
28 \text { May }\end{array}$ & $\begin{array}{l}20 \text { June } \\
21 \text { June } \\
16 \text { June } \\
19 \text { June }\end{array}$ & $\begin{array}{l}30 \text { June } \\
30 \text { June } \\
1 \text { July } \\
29 \text { June }\end{array}$ \\
\hline 2010 & $\begin{array}{l}\text { Arlington } \\
\text { Chilton } \\
\text { Janesville } \\
\text { Lancaster }\end{array}$ & $\begin{array}{l}23 \text { April } \\
21 \text { April } \\
27 \text { April } \\
22 \text { April }\end{array}$ & $\begin{array}{l}4 \text { May } \\
5 \text { May } \\
10 \text { May } \\
28 \text { April }\end{array}$ & $\begin{array}{l}15 \text { May } \\
19 \text { May } \\
20 \text { May } \\
14 \text { May }\end{array}$ & $\begin{array}{l}2 \text { June } \\
1 \text { June } \\
3 \text { June } \\
27 \text { May }\end{array}$ & $\begin{array}{l}15 \text { June } \\
16 \text { June } \\
21 \text { June } \\
14 \text { June }\end{array}$ \\
\hline
\end{tabular}

a Assessments for foliar diseases were made from Zadoks growth stage (GS) 30 (jointing) to GS 60 (beginning anthesis). Assessments for Fusarium head blight were made at GS 85 (soft dough). 
Table 5. Mean values for area under the disease progress curve and yield at four Wisconsin locations in 2009 and $2010^{\mathrm{a}}$

\begin{tabular}{|c|c|c|c|c|c|c|c|c|c|c|}
\hline Year, location & PM & Range & SLB & Range & LR & Range & FHBI & Range & Yield & Range \\
\hline \multicolumn{11}{|l|}{2009} \\
\hline Arlington & $369 \pm 84.6$ & $0-4,856$ & $504 \pm 52.8$ & $19-1,834$ & $624 \pm 57.1$ & $103-3,187$ & $0.03 \pm 0.01$ & $0-0.28$ & $5.7 \pm 0.07$ & $4.5-6.9$ \\
\hline Chilton & $346 \pm 65.9$ & $0-2,449$ & $350 \pm 36.7$ & $0-1,226$ & $416 \pm 26.5$ & $91-1,292$ & $0.01 \pm 0.00$ & $0-0.05$ & $\mathbf{5 . 9} \pm 0.07$ & $4.4-7.5$ \\
\hline Janesville & $35 \pm 5.5$ & $0-817$ & $\mathbf{5 2 1} \pm 33.1$ & $0-2,431$ & $387 \pm 19.7$ & $0-2,042$ & $0.01 \pm 0.00$ & $0-0.12$ & $4.2 \pm 0.03$ & $3.0-6.0$ \\
\hline Lancaster & $9 \pm 3.2$ & $0-636$ & $320 \pm 30.1$ & $0-3,432$ & $406 \pm 33.8$ & $0-3,546$ & $\mathbf{0 . 3 4} \pm 0.03$ & $0-2.28$ & $5.2 \pm 0.05$ & $3.5-7.1$ \\
\hline All locations & $109 \pm 15.2$ & $0-4,856$ & $421 \pm 18.8$ & $0-3,432$ & $428 \pm 16.8$ & $0-3,546$ & $0.13 \pm 0.01$ & $0-2.28$ & $5.0 \pm 0.04$ & $3.0-7.5$ \\
\hline \multicolumn{11}{|l|}{2010} \\
\hline Arlington & $72 \pm 9.1$ & $0-1,538$ & $\mathbf{1 3 0} \pm 10.6$ & $0-1,163$ & $15.6 \pm 4.9$ & $0-316$ & $0.00 \pm 0.00$ & $0-0.009$ & $\mathbf{6 . 0} \pm 0.03$ & $4.8-7.2$ \\
\hline Chilton & $495 \pm 30.2$ & $0-2,937$ & $78 \pm 8.7$ & $0-510$ & $17.5 \pm 2.4$ & $0-290$ & $0.00 \pm 0.00$ & $0-0.004$ & $4.6 \pm 0.04$ & $3.0-6.2$ \\
\hline Janesville & $2 \pm 0.5$ & $0-72$ & $23 \pm 1.9$ & $0-174$ & $0.7 \pm 0.1$ & $0-12$ & $\mathbf{0 . 1 3} \pm 0.02$ & $0-2.33$ & $4.7 \pm 0.05$ & $3.0-6.2$ \\
\hline Lancaster & $65 \pm 5.8$ & $0-385$ & $26 \pm 2.6$ & $0-274$ & $3.5 \pm 0.6$ & $0-77$ & $0.00 \pm 0.00$ & $0-0.20$ & $5.8 \pm 0.03$ & $3.9-6.9$ \\
\hline All locations & $162 \pm 10.3$ & $0-2,937$ & $65 \pm 3.9$ & $0-1,163$ & $9.6 \pm 1.4$ & $0-316$ & $0.03 \pm 0.01$ & $0-2.33$ & $5.3 \pm 0.03$ & $3.0-7.2$ \\
\hline
\end{tabular}

${ }^{a}$ Mean AUDPC values for the foliar diseases powdery mildew (PM), Septoria leaf blotch (SLB), and leaf rust (LR) and mean Fusarium head blight index $(\mathrm{FHBI})$ values. Yield $=$ mean grain yield (t/ha). Highest mean values for each disease and for yield are in bold. All means are \pm standard error. In 2009 sample sizes were Arlington, $n=50$; Chilton, $n=51$; Janesville, $n=142$; and Lancaster, $n=141$. In 2010, sample sizes were Arlington, $n=144$; Chilton, $n$ $=144$ or $n=134$ (yield); Janesville, $n=129$ or $n=125$ (yield); and Lancaster, $n=144$ or $n=141$ (yield).

Table 6. Correlation between grain yield (t/ha) and foliar disease (weighted disease severity) or Fusarium head blight (FHB) for 2009 and 2010 Wisconsin locations $^{\text {a }}$

\begin{tabular}{llcc}
\hline Year, location & \multicolumn{1}{c}{ Measure } & Correlation $^{\mathbf{b}}$ & $\boldsymbol{P}$ value \\
\hline 2009 & & & \\
Arlington & SLB GS 31-32 & 0.255 & 0.0252 \\
& SLB GS 39 & 0.229 & 0.0454 \\
Chilton & SLB GS 39 & -0.285 & 0.0090 \\
& SLB GS 60 & 0.216 & 0.0499 \\
Lancaster & LR GS 60 & -0.206 & 0.0018 \\
& FDK & -0.326 & $<0.0001$ \\
& FHB incidence & -0.223 & 0.0007 \\
& FHB severity & -0.203 & 0.0021 \\
2010 & FHB index & -0.224 & 0.0007 \\
Arlington & & & \\
Chilton & PM GS 39 & -0.160 & 0.0215 \\
& SLB GS 39 & -0.148 & 0.0216 \\
& PM GS 31-32 & -0.139 & 0.0309 \\
& PM GS 39 & -0.190 & 0.0030 \\
Lancaster & PM GS 60 & -0.245 & 0.0001 \\
& LR GS 39 & -0.158 & 0.0123 \\
\hline
\end{tabular}

$\overline{{ }^{a}}$ Foliar diseases include Septoria/Stagonospora leaf blotch complex (SLB), powdery mildew (PM), and leaf rust (LR). Correlations were calculated using weighted disease severity values for each disease at each of four assessment times. The first assessment time was at Zadoks growth stage (GS) 30 (jointing), the second was at GS 31-32 (first and second node), the third was at GS 39 (flag leaf emergence), and the fourth was at GS 60 (heading). Four measures of FHB were included in the correlations: percentage of Fusarium-damaged kernels (FDK), FHB incidence, FHB severity, and FHB index (the percentage of symptomatic spikelets per spike). FHB data were collected at GS 85 (soft dough).

b Correlations were performed using Pearson's correlation method. Only those correlations that were significant at $\alpha=0.05$ are shown.

highest levels of FHB. No significant correlations were found between FHB and yield in 2010, because FHB levels were very low at all sites.

SLB. At all locations, severity of SLB was higher in 2009 than in 2010 (Table 5). In 2009, SLB severity was highest at Janesville and Arlington. In 2010, severity was highest at Arlington (Table 5). In 2009, there was both an effect of SLB on grain yield $(P=0.005)$ and an SLB-location interaction $(P=0.014)$ (Table 7). Slope values are presented in Table 8 and indicate flat or slightly positive relationships across locations. In 2010, there was an SLB-location interaction $(P=0.008$; Table 7$)$, because slope values were either slightly positive at Arlington (slope $=0.07$ ) and Janesville (slope $=$ 0.06 ) or slightly negative at Chilton (slope $=-0.06$ ) and Lancaster (slope $=-0.05$ ).

Powdery mildew. Powdery mildew severity was variable among locations, with the highest severity at Arlington and Chilton in 2009 and at Chilton in 2010 (Table 5). In 2009, there
Table 7. Significant effects $(\alpha=0.05)$ of foliar diseases and Fusarium head blight (FHB) on grain yield for 2009 and 2010 in Wisconsin

\begin{tabular}{lllr}
\hline Year & Effect $^{\text {a }}$ & Factor & P value \\
\hline 2009 & SLB & SLB & $<0.0001$ \\
& $\ldots$ & Loc-SLB & 0.0143 \\
& PM & Loc-PM & 0.0074 \\
& FHB & Index & $<0.0001$ \\
& $\ldots$ & FDK & 0.0223 \\
2010 & SLB & Loc-SLB & 0.0083 \\
& PM & PM & 0.0002 \\
& $\ldots$ & Loc-PM & 0.0031 \\
& FHB & Loc-Index & 0.0170
\end{tabular}

$\overline{{ }^{a}}$ Foliar diseases include Septoria/Stagonospora leaf blotch complex (SLB), powdery mildew (PM), and leaf rust (LR). Area under disease progress curve values were used for all analyses. Four measures of FHB were included in the correlations: percentage of Fusarium-damaged kernels (FDK), FHB incidence, FHB severity, and FHB index (the percentage of symptomatic spikelets per spike). For both 2009 and 2010 in all models, grain yield was significantly affected by location (Loc), cultivar, and the location-cultivar interaction $(P<0.0001)$.

was an effect of the powdery mildew-location interaction on grain yield $(P=0.007$; Table 7$)$. Slope values varied by location, with either slightly negative slopes at Arlington (slope $=-0.04$ ) or Janesville (slope $=-0.02$ ) or slightly positive at Chilton (slope $=0.02$ ) and Lancaster (slope $=0.01$ ) (Tables 7 and 8). In 2010, there was a significant effect of powdery mildew on grain yield $(P=0.0002$; Table 7$)$. The highest powdery mildew severity in either year was observed at Chilton, where there was a significant negative effect of powdery mildew on yield (slope $=-0.23$; Tables 5 and 8; Fig. 1). Due to a significant interaction effect between location and powdery mildew $(P=0.003)$, there were different and smaller negative relationships between powdery mildew and grain yield at Arlington (slope $=-0.003$ ), Janesville (slope $=-0.003)$, and Lancaster $($ slope $=-0.07)$ (Tables 7 and 8; Fig. 1).

FHBI value and wheat leaf rust. FHBI values were low in both 2009 and 2010, with the highest indices at Lancaster in 2009 and Janesville in 2010 (Table 5). There was an effect of FHBI value on grain yield in $2009(P<0.0001)$ and a location-FHBI interaction $(P=0.017$; Tables 7 and 8$)$.

Leaf rust severity was higher in 2009 than 2010 at all locations (Table 5). However, there was no evidence of an effect of leaf rust on grain yield in $2009(P=0.823)$ or in $2010(P=0.467)$.

Effect of fungicides on disease severity and grain yield. In both 2009 and 2010 at Janesville, conditions for disease development were less favorable and, in general, disease severity was considered low compared with other locations (Table 5). There was no evidence of an effect of foliar fungicide on either AUDPC or grain yield at Janesville in 2009 and $2010(P>0.05)$. 
Table 8. Slope values for the regression line between transformed disease values (area under the disease progress curve) and grain yield (t/ha) for significant location (Loc)-disease interactions in Wisconsin $(\alpha=0.05)$

\begin{tabular}{lcccc}
\hline & \multicolumn{4}{c}{ Slope } \\
\cline { 2 - 5 } Year, source $^{\mathrm{a}}$ & Arlington & Chilton & Janesville & Lancaster \\
\hline 2009 & & & & \\
Loc-SLB & 0.26 & 0.02 & -0.02 & 0.07 \\
Loc-PM & -0.04 & 0.02 & -0.02 & 0.01 \\
2010 & & & & \\
Loc-SLB & 0.07 & -0.06 & 0.06 & -0.05 \\
Loc-PM & 0.00 & -0.23 & 0.00 & -0.07 \\
Loc-FHBI & -2.09 & -9.20 & -2.85 & -0.85 \\
\hline
\end{tabular}

Source of variation: Septoria/Stagonospora leaf blotch complex (SLB) and Fusarium head blight index (FHBI) were log transformed in both 2009 and 2010; powdery mildew (PM) was square root transformed in 2009 and $\log$ transformed in 2010.

\section{Discussion}

Disease, location, and cultivar have all been shown to influence wheat grain yield $(1,12,27)$. All of these factors were found to have an effect on grain yield in Wisconsin in 2009 and 2010. Powdery mildew was the disease with the greatest observed impact on grain yield. In 2009, the magnitude of the relationship between disease and grain yield was very small. By contrast, the effect of powdery mildew on grain yield was much larger at Chilton in 2010. This location had the highest powdery mildew severity of any location in either 2009 or 2010 (Table 6; Supplementary Table 1). As a result, the powdery mildew resistance of cultivars at this location was more likely to be challenged than in other locations. To illustrate, when comparing 'Hopewell', which carries moderate resistance to powdery mildew, with 'Kaskaskia', which is susceptible to powdery mildew, there was a $5 \times$ difference in mean AUDPC (Supplementary Table 1). Similar checks were also noted for other wheat cultivars where information about resistance or susceptibility to powdery mildew was known. This large negative relationship is consistent with previous research that has shown that, at locations where powdery mildew is severe, losses upward of $40 \%$ can occur on susceptible cultivars $(2,10)$. These data demonstrate that powdery mildew is capable of causing significant yield loss in Wisconsin, which fits well with previous research where there were yield responses to foliar fungicide application depending on whether the cultivar was resistant or susceptible to powdery mildew (unpublished). Although negative correlations were observed between disease severity and grain yield at some assessment times, there was no clear pattern to indicate critical points at which any of the diseases most strongly influence yield. This may be due to the relatively low disease severity in several locations in 2009 and 2010. The collection of data from additional locations with moderate or high disease severity may provide enough additional information to develop critical points for the diseases seen in Wisconsin. However, until more data about critical points become available, it may be necessary for Wisconsin growers to scout wheat fields throughout the growing season and to consider the cumulative progress of disease over the course of the season rather than disease severity at a specific time point when making management decisions.

Except for several comparisons for powdery mildew (see previous paragraph), it was difficult to clearly differentiate wheat cultivars based on location, disease, and yield using the methods applied here. Although differences among the cultivars for disease or yield (i.e., critical point assessments) would not be unexpected, the lack of any strong correlation suggests that a different method is needed to simultaneously examine disease and yield for a better understanding of cultivar performance in Wisconsin. Although there were no strong relationships observed between grain yield and SLB, leaf rust, or FHB, the results do suggest directions for future study. Results of our analyses on the effect of SLB on grain yield indicated either flat or positive slopes. It is difficult to draw specific conclusions about this result because previous research

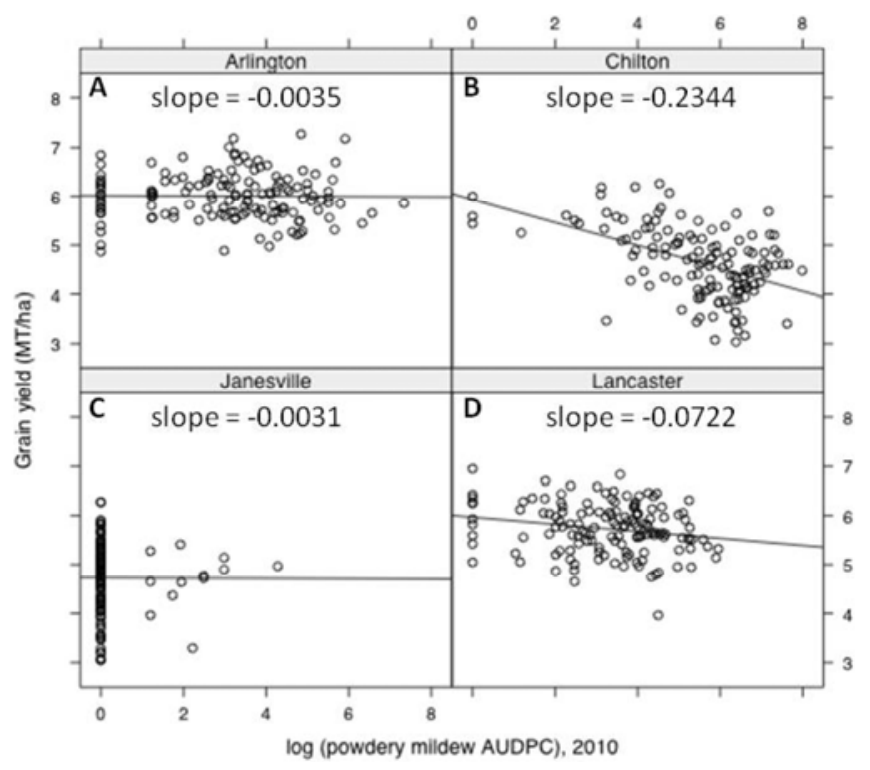

Fig. 1. Linear regression of log-transformed powdery mildew area under the disease progress curve values plotted against grain yield (t/ha) for A, Arlington; $\mathbf{B}$, Chilton; C, Janesville; and D, Lancaster Wisconsin locations in 2010.

does not support such a response $(2,13)$. Further research is needed to elucidate the relationship between SLB and yield in Wisconsin.

Interestingly, although the severity of leaf rust was high relative to other diseases in 2009 , no effect of leaf rust on grain yield was observed in either 2009 or 2010 . Leaf rust has been shown to be capable of causing significant yield losses, particularly when infection is severe on the flag leaf (11). The absence of a significant effect suggests that leaf rust disease severity may not have exceeded the threshold for yield loss in 2009 or 2010. Additional research needs to be done to determine the thresholds for yield loss associated with this disease. Further work is also needed to determine whether there are critical times of leaf rust onset and to assess the risk of yield loss due to leaf rust in Wisconsin.

FHBI values were highly variable among locations, with the highest values observed at Lancaster in 2009 and Janesville in 2010. Although very large negative relationships were observed between FHBI and grain yield in 2009, FHB levels were extremely low in all location-years and it is likely that these results do not provide biologically relevant information about the impact of FHB on grain yield. Environmental conditions at the time of flowering are known to be important for the development of FHB because this is when the most damaging infections are initiated $(2,16)$. For this reason, FHB epidemics tend to occur less commonly and are more highly dependent on local weather conditions during a specific time period than the foliar diseases. Future results obtained during an "epidemic year" may provide more insight into the importance of FHB in Wisconsin.

The most consistent factors determining grain yield in our trials appear to be cultivar and location. Given that growers tend to base their cultivar selections on yield characteristics, it is likely that breeding efforts have been focused on yield over other traits (3). Within each location, there was significant variation in grain yield, with approximately 2 to $3 \mathrm{t} / \mathrm{ha}$ difference in yield between the highest- and lowest-performing cultivars (Table 5). Although this difference in yield is likely due largely to genetic differences among cultivars, the location-cultivar interaction effect observed in both 2009 and 2010 indicates that the combination of these two factors is also an important determinant of yield performance in Wisconsin (Supplementary Table 1).

In 2009, yields at Janesville were lower than at the other three locations. The reasons for this are uncertain; however, it is likely that a combination of physical and environmental factors were involved. Disease may also have been a small factor. For both SLB and powdery mildew, the relationship between disease and yield 
was slightly negative at Janesville in 2009. In 2010, both Chilton and Janesville had low yields compared with the other locations. As described above, powdery mildew was a significant factor affecting yield at Chilton in 2010. However, the particularly low yield at this location was probably also due to unusually high rainfall in Chilton at the end of July, which delayed harvest and reduced the test weight of the grain. Disease pressure was very low at Janesville in 2010. For this reason, low yield at this location was likely due to very late planting rather than to disease pressure.

In addition to its negative effect on yield, we speculate that the late planting of the Janesville crop in 2010 may have limited the establishment of pathogens in the fall. In 2010, mean AUDPC values for all the foliar diseases were lowest at Janesville. At the other three locations, which were planted approximately 1 month earlier than the Janesville location, there may have been greater opportunity for pathogen establishment before the onset of winter conditions. Based on observations made during 2010 for powdery mildew, especially at Chilton, we speculate that it was very unlikely that powdery mildew established in the fall at Janesville. Further research needs to be done to determine the role of fall infection on the establishment of secondary infections in the early spring.

The application of a foliar fungicide was not found to affect grain yield at Janesville. Over the 2 years, the disease incidence and severity were fairly low at this location. This result from our fungicide work is consistent with the findings of Christ and Frank (7) and Guy et al. (15), who observed that the greatest level of fungicide efficacy is achieved when disease severity is high (4). Although this finding does not give specific information about fungicide control of diseases in Wisconsin, it does underscore that fungicides are likely to be most effective for disease control rather than for improving general plant health, an off-label application which has garnered recent interest.

Based on analysis of AUDPC values, powdery mildew was found to reduce grain yield of winter wheat in Wisconsin. This information indicates that growers can reduce yield loss in powdery mildew epidemic years by selecting cultivars with resistance to $B$. graminis. This finding also indicates that powdery mildew should be a focus of breeding for cultivars introduced in Wiscon$\sin$. The research presented here is a first step toward understanding the impact of disease on yield of winter wheat in Wisconsin. As research on winter wheat in the state continues to expand and more information is collected, it may be possible to develop disease thresholds for the cultivars most commonly planted in the state.

\section{Acknowledgments}

We thank C. Grau and A. Peltier for extensive critical review of this manuscript; C. Mattupalli and N. Koval, who reviewed an earlier draft of this manuscript; and N. Keuler, for statistical consulting.

\section{Literature Cited}

1. Basford, K. E., and Cooper, M. 1998. Genotype x environment interactions and some considerations of their implications for wheat breeding in Australia. Aust. J. Agric. Res. 49:153-174.

2. Bockus, W. W., Bowden, R. L., Hunger, R. M., Morrill, W. L., Murray, T. D., and Smiley, R. W. 2010. Compendium of Wheat Diseases and Pests, 3rd ed. American Phytopathological Society, St. Paul, MN.

3. Calderini, D. F., Reynolds, M. P., and Slafer, G. A. 1999. Genetic gains in wheat yield and associated physiological changes during the twentieth century. Pages 351-377 in: Wheat: Ecology and Physiology of Yield Determination. E. H. Satorre and G. A. Slafer, eds. Food Products Press, Binghamton, NY.

4. Carignano, M., Staggenborg, S. A., and Shroyer, J. P. 2008. Management practices to minimize tan spot in a continuous wheat rotation. Agron. J. 100:145-153

5. Carranza, M. R., Moschini, R. C., Kraan, G., and Bariff, J. H. 2007. Ex- amination of meteorology-based predictions of Fusarium head blight of wheat grown at two locations in the southern Pampas region of Argentina. Australas. Plant Pathol. 36:305-308.

6. Carretero, R., Serrago, R. A., Bancal, M. O., Perello, A. E., and Miralles, D. J. 2010. Absorbed radiation and radiation use efficiency as affected by foliar diseases in relation to their vertical position in the canopy in wheat. Field Crop Res. 116:184-195.

7. Christ, B. J., and Frank, J. A. 1989. Influence of foliar fungicides and seed treatments on powdery mildew, Septoria, and leaf rust epidemics on winter wheat. Plant Dis. 73:148-150.

8. Conley, S., Esker, P., Martinka, M., Gaska, J., and Lackermann, K. 2009. Wisconsin Winter Wheat Performance Tests-2009. Univ. Wisc.-Madison Coop. Ext. A3868.

9. Conley, S., Esker, P., Martinka, M., Gaska, J., and Lackermann, K. 2010. Wisconsin Winter Wheat Performance Tests-2010. Univ. Wisc.-Madison Coop. Ext. A3868.

10. Cunfer, B. M. 2002. Powdery Mildew. In: Bread Wheat: Improvement and Production. B. C. Curtis, S. Rajaram, and H. Gomez Macpherson, eds. Food and Agriculture Organization of the United Nations, Rome. http://www.fao. org/DOCREP/006/Y4011E/y4011e00.htm

11. Eversmeyer, M. G., and Kramer, C. L. 2000. Epidemiology of wheat leaf and stem rust in the central great plains of the USA. Annu. Rev. Phytopathol. 38:491-513.

12. Everts, K. L., and Leath, S. 1992. Effect of early season powdery mildew on development, survival, and yield contribution of tillers of winter wheat Phytopathology 82:1273-1278.

13. Eyal, Z., Scharen, A. L., Prescott, J. M., and van Ginkel, M. 1987. The Septoria Diseases of Wheat: Concepts and Methods of Disease Management. CIMMYT, Mexico, D.F.

14. Gooding, M. J., Dimmock, J. P. R. E., France, J., and Jones, S. A. 2000. Green leaf area decline of wheat flag leaves: the influence of fungicides and relationships with mean grain weight and grain yield. Ann. Appl. Biol. 136:77-84

15. Guy, S. O., Oplinger, E. S. Wiersma, D. W., and Grau, C. R. 1989. Agronomic and economic response of winter wheat to foliar fungicides. J. Prod. Agric. 2:68-73.

16. Hollins, T. W., Ruckenbauer, P., and DeJong, H. 2003. Progress towards wheat varieties with resistance to Fusarium head blight. Food Control $14: 239-244$.

17. Kelley, K. W. 2001. Planting date and foliar fungicide effects on yield components and grain traits of winter wheat. Agron. J. 93:380-389.

18. Lafitte, H. R., and Courtois, B. 2002. Interpreting cultivar $\mathrm{x}$ environment interactions for yield in upland rice: assigning value to drought-adaptive traits. Crop Sci. 42:1409-1420.

19. Large E. C., and Doling, D. A. 1962. The measurement of cereal mildew and its effect on yield. Plant Pathol. 11:47-57

20. Lipps, P. E., and Madden, L. V. 1989. Assessment of methods of determining powdery mildew severity in relation to grain yield of winter wheat cultivars in Ohio. Phytopathology 79:462-470.

21. Littell, R. C., Milliken, G. A., Stroup, W. W., Wolfinger, R. D., and Schabenberger, O. 2006. SAS for Mixed Models, 2nd ed. SAS Institute Inc. Cary, NC.

22. Madden, L. V., Hughes, G., and van den Bosch, F. 2007. The Study of Plant Disease Epidemics. American Phytopathological Society, St. Paul, MN.

23. Madden, L. V., and Paul, P. A. 2009. Assessing heterogeneity in the relationship between wheat yield and Fusarium head blight intensity using randomcoefficient mixed models. Phytopathology 99:850-860.

24. National Agricultural Statistics Service. 2008. U.S. and all states datawinter wheat. www.nass.usda.gov/QuickStats/PullData_US.jsp

25. Ransom, J. K., and McMullen, M. V. 2008. Yield and disease control on hard winter wheat cultivars with foliar fungicides. Agron. J. 100:1130-1137.

26. Simmons, S. R. 1987. Growth, development, and physiology. Pages 77-13 in: Wheat and Wheat Improvement, 2nd ed. E. G. Heyne, ed. American Society of Agronomy, Crop Science Society of America, and Soil Science Society of America. Madison, WI.

27. Slafer, G. A., and Satorre, E. H. 1999. An introduction to the physiologicalecological analysis of wheat yield. Pages 3-11 in: Wheat: Ecology and Physiology of Yield Determination. E. H. Satorre and G. A. Slafer, eds. Food Products Press, Binghamton, NY.

28. Wiik, L. 2009. Yield and disease control in winter wheat in southern Sweden during 1977-2005. Crop Prot. 28:82-89.

29. Yan, W., and Hunt, L. A. 2001. Interpretation of genotype by environment interaction for winter wheat yield in Ontario. Crop Sci. 41:19-25. 